\title{
BETWEEN POLISH AUTARKY AND RUSSIAN AUTOCRACY: THE JEWS, THE PROPINACJA, AND THE RHETORIC OF REFORM*
}

\author{
In memory of Professor \\ Jacob Talmon
}

The prominent position of Jews in various aspects of the production, distribution and vending of beer, vodka and other grain-based intoxicants in late-eighteenth-century Poland was noted by contemporaries and registers in the meager socio-demographic data available for the period. The Jewish innkeeper, particularly in the Eastern regions of Poland, was an important representative of the Dvorf Yid - the provincial Jew as recorded in memoirs, chronicles and travellers' accounts. ${ }^{1}$ In the middle of the eighteenth century, 20 to 30 percent of the Jewish population of Poland was estimated to be involved in some aspect of alcohol production and distribution - what came to be called the Propinacja. The census of 1764-65, organized shortly after the dissolution of the Council of Four Lands and

* I especially wish to thank the editors of the International Review of Social History for their careful attention and helpful comments. My appreciation is also expressed to Wendy Wipprecht for her devoted editorial assistance.

1 The Krechme, as it was called by the Jews themselves, was a general store, a hostel for travellers and their horses as well as a tavern and inn where food and drink could be procured. See, for example, Solomon Maimon's account in Sefer ha-yai Shlomo Maimon, transl. by Y. L. Baruch (Tel Aviv, 1953), pp. 79-82. For a description of a Jewish inn during the early nineteenth century, see J. L. Stephens, Incidents of Travel in Greece, Russia and Poland (2 vols; New York, 1838), II, p. 189. The character of the Jewish innkeeper has been immortalized in H. N. Bialik's famous poem "Avi", in Kol shirei Bialik (Tel Aviv, 1953), p. 347. I would also like to add the following description of Polish peasants, Polish Jews and their relations in the Polish territory annexed to the Austrian Empire, which is found in J. A. Demian, Darstellung der Oesterreichischen Monarchie (4 vols; Vienna, 1804), quoted in The Habsburg and Hohenzollern Dynasties in the Seventeenth and Eighteenth Centuries, ed. by C. A. Macartney (New York, 1970), pp. 195-97: "When the peasant drives to market, he calls in on the way there at several Jewish taverns, leaves the payment till the return journey, then on that repeats all his visits and drinks away half, sometimes all, the money he has made at the market. He swills down twenty to thirty glasses at a sitting. His wife is not a hairsbreadth behind him. On Sundays and holidays they walk to the church in their best clothes, but barefoot, carrying their boots under their arms. At the entrance to the village in which the parish church stands they put on their boots; after Divine Service they take them off again in the same place and then go into the taverns with their husbands or kinsfolk. There they drink brandy till 
designed to establish a new basis for taxation, reported that a majority of the Jews in villages and 15 percent of the Jews in towns were involved in the Propinacja. $^{2}$

Reaction against the high incidence of Jews in these enterprises began in the second part of the eighteenth century, and grew into a chorus of criticism by the turn of the century. While initiated in part by some who clearly would have liked to claim a greater share in these profits for themselves, the critique of Jewish involvement in the Propinacja soon became what appeared to be a principled assessment of the Jews' economic role. Conceptions of productivity, developed in the West under different socio-economic conditions, were applied to Jews by the reformers of the short-lived Polish Enlightenment. ${ }^{3}$ The involvement of Jews in the Propinacja was seen as proof that they were not only unproductive citizens,

sundown, without eating so much as a morsel of bread; then they start off, singing, for their villages, which are often a couple of leagues away, and often spend the whole night lying in heaps on the road. [...] At their frequent meetings the Jew enters into intimate conversation with him, listens to his complaints and often gives him sound advice. In these frequent conversations he learns what each peasant possesses, what he has to sell, what he is short of and what he can do without. Now the Jew is already master of the poor helot's property. Very soon the peasant drinks himself into indebtedness to the Jew, and this does not worry the creditor. [...] The peasant feels only his immediate need, and immediate relief of it is all he wants. So his household remains eternally in the same state of wretchedness, and the peasant's continued habit of regarding the Jew as his friend gradually engenders an unlimited confidence in the Jew which is infinitely advantageous to the latter. To remedy this evil the Austrian Government has prohibited Jews from leasing the taverns in the country and the towns, and in 1780 ordered that Jews might reside in villages only as agricultu ralists or craftsmen, because they had so corrupted the peasants as tavern-keepers. But this wise measure was relaxed. A decree of 1792 permitted Jewish distillers of brandy and all persons gaining their livelihoods from permitted trades, whether Jews or Christians, to continue to reside in the villages. The Jews have therefore gone on living in the villages, calling themselves distillers, while putting in a Christian as nominal licensee of the inn, but in reality continuing to practice the forbidden trade, and continuing to constitute a great danger for the population." While the political and economic conditions in Austria were different from those of Russia (described in this paper), the realia of the two areas, and the basic social relations between Jews and peasants there, were similar.

${ }^{2}$ Economic History of the Jews, ed. by N. Gross (New York, 1975), pp. 132-40. For an assessment of the census data upon which this estimate is based, see A. Tartakower, "Polish Jewry in the Eighteenth Century", in: Jewish Journal of Sociology, II (1959-60), pp. 110-14.

3 Poles referred to the economic position of West European Jews, and contrasted it with that of Polish Jews; the contrast became a basis for criticizing the latter, as illustrated in this remark from a Polish memoir: "For us who are accustomed to our Itziks and Moskes who sit in the stores and get the masses drunk, it is a wonder to see people from that nation and faith in other lands who are so useful and educated." Quoted in E. Ringelblum, "Hasidus un Haskoloh in Varshah in 18-Yahrhundert", in: Wachstein-Bukh (Vilna, 1939), p. 130. 
but that this group, which made up 10 percent of the Polish population, was significantly draining the vital resources of the Polish economy. Even within the Jewish community there were some who pointed to the limited vocational opportunities for Jews, but who nevertheless expressed some reservations about this source of revenue. ${ }^{4}$

Particularly vociferous in their condemnation of Jewish involvement in the Propinacja were the Russian service gentry and bureaucrats. Russian opinion becomes important at this time because the Russian autocratic state was increasing its influence over the "Commonwealth of the Gentry"; with the Partitions, it established actual hegemony over large sections

4 Jews had condemned the Jewish involvement in the Propinacja some years before. In 1759, two Frankists addressed a petition to the King of Poland and the Archbishop of Lvov, requesting land on which to settle (and protection from the Jews they were seperating from); they thought it necessary to assure their sponsors that they would seek honorable means of support: "For we do not suppose that one of our own will ever settle in a tavern to seek his sustenance by facilitating intoxication and by the use of Christian blood which the Talmudists are accustomed to do." Quoted in M. Balaban, Le-toldot te-nu-'ah ha-Frankit (Tel Aviv, 1934), p. 205. The association between the Propinacja and the blood libel calls for further investigation. See H. Levine, "Gentry, Jews and Serfs: The Rise of Polish Vodka", in: Review: A Journal of the Fernand Braudel Center for the Study of Economies, Historical Systems, and Civilizations, IV (1980-81), pp. 223-50. The Maggid of Kremnic, Jacob Israel Halevi, called the Propinacja "a profession of robbers". See "Yitron ha-'or", Agudat ei'-zov (Zolkiev, 1782), p. 23, cc. 2-4, quoted in M. Piekaz, Bi-yemei Șemihat ha-Hasidut (Jerusalem, 1978), p. 71. For the attitudes of some Maskilim during the Four-Year Sejm, see below, pp. 75f., and also M. Levin, Erkhei hevrah ve-kalkalah beidiyologiyah shel te-kufat ha-Haskalah (Jerusalem, 1975), pp. 104-08. Even recent Jewish historians have treated the subject apologetically. Simon Dubnov, for example, emphasizes the impoverishment of Polish Jewry; lacking other vocational opportunities, they took over this demeaning task from the corrupt and indolent gentry. See his History of the Jews, transl. by M. Spiegel (S. Brunswick, N. J., 1967-73), IV, p. 83. Even the economic historian Ignacy Schipper fails to point to the economic functions of the Propinacja. He calls it "an old sickness which became more serious in the days of Stanislav August". He explains that the "enlightened" people of the generation - those who could transcend their own interests - condemned it as part of the exploitation of the peasantry. The riots of 1768 in the Ukraine moved the gentry to give up the part of their income that was derived from this harmful source. Jews were therefore eliminated from these occupations and the Jewish population of the small towns in the East dwindled. Schipper praises "Polish statesmanship" in discussing the efforts to promote reform among the Jews. See his "An Economic History of Polish and Lithuanian Jewry from the Earliest Period until the Partitions" (in Hebrew), in: Beit Yisra'el be-Polin, ed. by I. Halperin (2 vols; Jerusalem, 1948), I, p. 197. Jewish historians take opposing positions concerning the Polish reformers' intentions and capacity to bring about any change in Poland in general, and to positively affect the Jewish situation in particular. A contemporary Polish historian, Jerzy Jedlicki, presents a more balanced view of the reform movement. See his article, "Social Ideas and Economic Attitudes of Polish EighteenthCentury Nobility: Their Approach to Industrial Policy", in: Fifth International Congress of Economic History, Leningrad, August 10-14, 1970, I: History of Economic Thought, pp. 89-103. 
of Poland - sections which had a significant Jewish population. The Russians' harping on the Jews' deleterious effects counterpointed the ostensibly more liberal and positive tone of their official pronouncements about the Jews that reflected the "Enlightened Absolutism" of Catherine II and the influence of Western ideas in official circles. Jewish management of the Propinacja was causally linked to the problems of the peasants their low standard of living, their rebelliousness and destructiveness, and declining agricultural yields - problems which were undermining serfdom as an institution. Eliminating the Jews from the Propinacja was viewed as the necessary condition for increasing Jewish productivity; both were prominent themes in the literature calling for the reform of the Jews. But when edicts banning the Jews from the manufacture and marketing of alcohol were promulgated during the nineteenth century, they brought instantaneous ruin to thousands of Jewish families when and where they were enforced.

Recent studies of the economic functions of the production of grain-based intoxicants in economically underdeveloped regions suggest a new interpretation of the Jewish role in the Propinacja and its relationship to Jewish productivity. ${ }^{5}$ Specifically in Poland in the early modern period, the Propinacja has been shown to be integral to the economic viability of feudalism. ${ }^{6}$ The feudal economy was organized in response to rising grain prices on international markets; it also presumed an unlimited supply of

5 For example, a study of the manufacture and consumption of whiskey in the areas west of the Appalachian Mountains in the early nineteenth century presents an interesting parallel. Before the Erie Canal was built, farmers found it considerably more profitable to transport their grain crops to the Eastern regions of the American Republic in the form of alcohol. See W. J. Rorabaugh, The Alcoholic Republic: An American Tradition (New York, 1979), pp. 77-92, and P. Park, "Industrialization and Alcoholism: Toward a Structural Explanation", a paper read at the annual meeting of the Society for the Study of Social Problems, "The Social Production of Drug and Alcohol Problems", Boston, 26 August 1979.

6 Here I follow Witold Kula's analysis, as set forth in An Economic Theory of the Feudal System: Towards a Model of the Polish Economy 1500-1800, transl. by L. Garner (London, 1976). In this work, Kula does not mention Jewish involvement in the Propinacja. But see his Problemy i Metody Historii Gospodarczej (Warsaw, 1963), pp. 76-77, where he does call for an examination of the economic activities of Jews as an integral part of the economic history of Poland in particular. For a more detailed economic analysis of the Jewish position in the Propinacja, see Levine, "Gentry, Jews, and Serfs", loc. cit., pp. 223-41. For a discussion of Kula's model of Polish feudalism, see L. Makkai, "Neo-Serfdom: Its Origin and Nature in East Central Europe", in: Slavic Review, XXXIV (1975), pp. 225-38, and A. Kamiński, "Neo-Serfdom in Poland-Lithuania", ibid., pp. 253-68. 
peasants who could be enserfed. The gentry sought to maintain, under any and all circumstances, a closed system of monetary circulation; this entailed keeping cash payments for any services to a minimum and made the feudal labor contract - and the domination of the peasantry it ensured an end to itself. This policy enabled the gentry to use all revenues from their estates to procure imported luxury items. At the same time, patriarchalism reinforced the nobleman's desire to maintain the economic autarky of his estate. This emphasis is expressed by a late-sixteenth-century writer on economic organization and bookkeeping: "It is not only harmful, but shameful to buy with money, as a result of neglectfulness, what could be had without expense."7

The policy of closed monetary circulation prompted the gentry to siphon off any surplus the peasants might generate. It also encouraged them to undermine the economies of the town and the burgher class. The serfs would then have no markets in which to dispose of surplus agricultural produce; nor could they generate a cash surplus which could be used to purchase manufactured goods and thus remove wealth from the estate. It further provided the economic framework for the Arenda, the system of concessions which the gentry offered primarily to Jews from the sixteenth century on. Through this arrangement, absentee gentry landlords leased their whole estate or specific enterprises such as a mine, a toll station on a road or an inn. The gentry not only procured Jewish managerial skills, particularly in high-risk situations, but also enlisted Jews into the very economy of the feudal estate. The decentralization of political authority over the Jews, shifting an increasing number of them from the jurisdiction of the monarchy to that of the feudal estates, enabled the gentry to claim tax revenues from the Jews formerly pledged to the monarchy. In addition, it rendered the Council of Four Lands, the Jewish super-communal structure whose central functions included taxation, both more necessary and more impracticable. The gentry also gained by this shift of Jews into their domain in another way: Jewish trade and crafts activities were placed more firmly under gentry control. This further reduced the serfs' opportunities to spend money outside the feudal estates.

During the seventeenth century, as grain shipment to international markets became more difficult because of wars and peasant rebellions, and as Polish grain prices on those markets began to decline, the gentry had to find local outlets for surplus grain in order to maintain their income from grain in spite of this adverse market situation, and thereby to ensure the profitability of their estates and their standard of living. The conversion

${ }^{7}$ Quoted in Kula, An Economic Theory of the Feudal System, op. cit., p. 141. 
of increasing quantities of grain into intoxicants and the distribution of alcohol among the serfs provided a convenient and reliable means of maintaining profits and cash supplies for importing luxury items despite a generally low level of monetization. Siphoning off the serfs' surplus cash by these methods had an additional, non-economic benefit: encouraging the drinking habits of the peasants, even forcing them to purchase a minimum quantity of the local brew, not only ensured revenues but facilitated controlling that increasingly rebellious workforce. And since labor was plentiful and cheap, and promised to remain so, the gentry never considered how harmful this practice was to the serfs' health. That system's utility was stressed by the eighteenth-century magnate Prince Józef Czartoryski: "Without the sales of the propinacja we would not be able to assure ourselves of a regular income in currency. [. . . In our country the vodka distilleries could be called mints, because it is only thanks to them that we can hope to sell off our grain in years when there is no famine."8

Again the Jews proved useful to the gentry. As part of the A renda system, Jews became heavily involved in the manufacture, distribution and sale of grain-based intoxicants; as innkeepers, they were the most visible representatives of this enterprise and of its economic functions of surplus extraction. They helped the gentry to profit from economic stagnation even economic retrogression - and from the uncertain returns of the international grain market. Saving the system of economic autarky enabled the gentry to control the Jews, the burghers and the serfs more effectively by depriving them of the modicum of freedom which participation in exchange markets allows, and by weakening the central government, which could make contending claims for the control of these classes.

With this analysis of the feudal economy in mind, it might be said that the Jewish role in the Propinacja contributed at least in the short term to the balancing of conflicting results of that system. As the students of Polish feudalism emphasize, the very methods of social and economic control of the serfs that the gentry had devised to further their own interests eventually incited the serfs to rebel against and to sabotage those same interests. Jewish management of the Propinacja enabled the gentry to enact their theoretical notions of domination and autarky in spite of the pressures of other realities. The intoxication and impoverishment of the serfs made them more docile and controllable, contributing to their exploitation. Inducing the peasants to drink made them more indebted and siphoned off any surplus capital which they may have spent outside of that feudal economy which the gentry sought to control as a closed system of

8 Ibid., p. 137. 
circulation. That the peasants were encouraged to drink away money which they might have used to purchase manufactured goods or to pay their church tithes in the Jewish-managed taverns did not endear the Jews to other sectors of the Polish population such as the town merchants and clergy who sustained the loss. Ultimately, however, the Propinacja may have had a less than favorable effect on gentry economic interests as well by reducing the productivity and the reliability of the serfs as a labor-force. The outbreaks of peasant violence, increasing in frequency from the middle of the seventeenth century, were often but not exclusively aimed at the Jewish vendors of vodka and their co-religionists. Gentry landlords at times had to share refuge and plan common strategies with their Jewish lease-holders against the murderous peasant mobs.

The gentry, who derived the greatest political and economic benefits from the Propinacja, could pass on both the risk and the blame for its deleterious side-effects to their Jewish agents. At the same time, the gentry could join other sectors of Polish society, with whom they were otherwise at odds (including even the serfs), in condemning the Jewish exploiters. That the gentry profited so directly from the Propinacja did not prevent them from expressing moral indignation at the expense of the Jews. The virulence of anti-Jewish attacks, including the resurgence of the nefarious blood libel in the eighteenth century, exemplified and perhaps provided the symbolic forms through which that indignation was expressed. As the failures of feudalism as a socio-economic system became more evident, even to the most fatuous of the Polish gentry, in the course of the eighteenth century, the Propinacja's role as a device to save the failing system came under new scrutiny. Questions of Jewish productivity were linked to the failure. What was judiciously avoided was a comprehensive analysis of Polish feudalism and its autarky, which had been supported by the Propinacja and by the Jews connected with it. That the Propinacja could actually have been deemed a "productive" enterprise under the prevailing economic conditions could not be acknowledged. The old indignation was now given further expression, but in a new key: the rhetoric of reform.

\section{II}

If we examine the Polish publicistic literature on the Propinacja, one fact strikes us. The earliest discussion of the Propinacja has little to do with Jewish involvement; instead, it addresses the distribution of the monopoly's benefits among the different sectors of Polish society. An early complaint about the vending of alcohol is registered by the gentry against 
the clergy. During the Sejm of 1719, the clergy comes under attack for not paying enough taxes, for accruing too much land through bequests, and for removing too much Polish wealth by sending extravagant gifts to Rome. At the same time, the Church is criticized for profiting too greatly from alcohol sales in inns located on its lands. Here, opposition to the Propinacja is registered not in any principled terms, but simply with regard to the removal of money that the gentry wanted to circulate within the feudal economy. ${ }^{9}$

Another example of this competition for the Propinacja's profits may be seen in a debate held in the Polish Sejm in 1775. This debate already touches upon the desirability of Jewish involvement in the Propinacja. Since the magnates who raised the point were trying to undermine the economic position of the lower gentry and no longer needed Jewish managers and capital to run the Propinacja, they decided to complete their monopoly on that profitable enterprise by pushing out the Jews. A member of the upper gentry complained that Jewish innkeepers were competing unfairly with the gentry; he alleged that Jews undersold and thus attracted more customers than non-Jews because they cheated the peasants to acquire grain at prices below the market level; and he concluded that Jews should therefore be barred from the Propinacja. But if Jewish involvement in the Propinacja was a liability to one class, it was an asset at this time for another. Another delegate vociferously opposed this measure, calling it a violation of the "laws of nature". For the poorer gentry, who could not afford the capital outlay to manufacture drink, granting concessions to Jews was a major source of income; any abridgement of this privilege conflicted with their economic interests and legal prerogatives. Here, both opposition to and support for Jewish involvement in the Propinacja are couched in economic terms. ${ }^{10}$

The assessment of the Propinacja in relation to the dispute over the distribution of wealth was soon balanced by a consideration of its injurious effects on the serfs. The first to make this explicit were the Russian administrators of the newly acquired Polish territories - the consolidators of autocracy -, who enjoyed no direct economic benefit from the Propinacja. From the First Partition of Poland (1772) until well into the nineteenth century, any investigation of peasant unrest, often initiated after crop

9 A. Gieysztor et al., History of Poland (Warsaw, 1968), p. 300.

${ }^{10}$ E. Ringelblum, Kapitelen geshikhte fun amoliken yiddishen leben in Polin (Buenos Aires, 1953), pp. 122-24. Israel Halperin claims that the lower and middle gentry generally opposed the magnates' efforts to grant leases and concessions to Jews. See his collection of essays, Ye-hudim ve-Yahadut be-Mizrah Eiropah (Jerusalem, 1969), pp. 285-86. 
failures and peasant rebellions, pointed an accusing finger at the odious Jewish producers and purveyors of peasant misery. Dark pictures were painted of evil Jews who withheld grain from starving peasants because it was more profitable to use it to make alcohol than bread.

A year after the First Partition of Poland, a minor Russian official from the district contiguous with the newly annexed Polish territory made a survey of Eastern Poland. In his report, Mikhail Kakhovskii noted grain shortages and inflation, attributed them to Jewish profiteering and shady practices, and outlined their supposed effect on Polish serfs. The Jews, he proceeded to indicate, secured available grain supplies through and for their trade in alcoholic beverages. Wherever they could, they sold drink to the peasants at high prices. The debt that the peasants owed to the Jews increased. The Jews placed special grasses in the drink which they served making the peasants fall asleep, at which point the Jews robbed and falsely registered credit extended to the peasants. The Jews eventually collected from the peasants' grain. Moreover, the large supplies of grain which the Jews exploited by whatever device artificially inflated the price of grain, creating shortages and leading to the general decline of the population. ${ }^{11}$ Kakhovskii recognized that the Jews were acting as the gentry's agents in this enterprise. But the Jews received all the blame, while the Polish gentry were presented as innocent observers who had not fully considered the consequences of the Propinacja. This memorandum had a great deal of influence on the publicistic literature of both Poland and Russia in the years that followed.

Jewish involvement in the Propinacja is examined in the mass of publicistic literature written around the time of the Four-Year Sejm (1788-92). Among the most important pamphlets submitted in defense of the Jews was "The Way of Forming Jews into Useful Citizens of the Country" by the liberal aristocrat Mateusz Butrymowicz. This pamphlet, published in February 1789, was probably a re-edited version of an anonymous pamphlet - "Jews, or the Obvious Need for the Reform of the Jews in the Lands of the Polish Commonwealth, by a Nameless Citizen" written earlier in the 1780 's. Butrymowicz deals with the social situation of Jews in the Commonwealth. "That they are not included in any of the

11 J. Slutsky and M. Buba, "The History of the Jews in Russia in the Eighteenth Century" (in Hebrew), in: He-'Avar, XIX (1971), pp. 74-78. For an analysis of the factors influencing Russian policies toward Jews in the late eighteenth century, see Sh. Ettinger, "The Foundations and Purposes in the Formation of the Russian Government's Jewish Policy during the Partitions of Poland" (in Hebrew), ibid., pp. 20-34. The different approaches of Russian and Polish officials to Jewish communal affairs are examined in M. Nadav, "Rabbi Avigdor ben Hayim and His Battle against Hasidism in Pinsk and Lithuania" (in Hebrew), in: Șion, XXXVI (197I), pp. 200-19. 
existing classes", he argues, "has been a grave constitutional and legislative error"; and he goes to to show that years of discrimination and persecution have drained them of money. Because of vocational and residential restrictions, and the landlords' desire for profit, Jews live primarily in the countryside; there, they run inns and sell spirits to peasants, and often victimize them. (Here Butrymowicz repeats Kakhovskii's accusations that Jews drug the liquor they sell in order to hasten intoxication, which allows them to overextend credit or even pad the peasants' bills.) To correct this sitation, Butrymowicz proposes that Jews be placed in the burgher class and forced to wear Christian clothes, which would admit them to Christian society and thus end their disgrace. They should also be driven from rural innkeeping into town-based trades and crafts; if they are to be innkeepers, their inns should be located only in towns. There competition and municipal supervision of quality and prices would ensure good service and provide additional revenue for the town government; at the same time, Jewish exploitation of peasants would be ended. ${ }^{12}$ In a draft resolution entitled Reforma $\dot{Z} y d o ́ w$, which Butrymowicz submitted to the King several months later (4 december 1789), he argues more directly that Jews should be banned from innkeeping and from the liquor business. ${ }^{13}$

Herszel Josefowicz, the rabbi of Chelm, answers Butrymowicz by arguing that Jews indeed need some of the reforms the latter suggests, but also points out that his program is on the whole superficial and misguided, because his position as a landlord warps his perspective. In the past, Josefowicz argues, the Jews were useful to the country. They still are diligent, humble and loyal servants, even though they are despised by all sectors of Polish society. Responding to Butrymowicz's accusation that the Jews who run country inns and sell spirits spread drunkenness among the peasants, Josefowicz asserts that they serve both landlords and peasants in this capacity and make very small profits. The notion that Jews drug the liquor they serve the peasants is proved simply senseless: after all, sleeping peasants buy no drinks. ${ }^{14}$

During this period, other Jewish publicists and petitioners also commented upon the Propinacja. In 1790, corresponding - perhaps not by accident - with the Four-Year Sejm, Moses Marcuse published a book, Sefer Ha-refu-'ot. Marcuse proposes internal reforms, including improved hygiene in Jewish homes and the planting of kitchen gardens to provide employment and ensure self-sufficiency for Jews. If Jews grow their own

12 Collected in A. Eisenbach et al., Materialy z Historii Sejmu Czteroletniego (6 vols; Wroclaw, 1969), VI, pp. 78-93.

13 Ibid., pp. 118-28.

14 Ibid., pp. 98-105. 
vegetables, Marcuse says, they will not need cash to buy them; they can then abandon innkeeping, which is both tainted and unprofitable, and concentrate on gardening. ${ }^{15} \mathrm{Dr}$ Solomon Polonus of Vilna submitted a proposal entitled Projekt względem $\dot{Z} y d o w$ in the first months of 1792. It was a collection of demands appended to Polonus's translation of Father Grégoire's speech to the French National Assembly, in which he advocated the extension of greater civil rights to Jews in France. In his own section of the work, Polonus argues for removing Jewish residential and vocational restrictions, and proposes changes within the Jewish community, such as schooling Jewish children in Polish and modifying Jewish garb and customs. Jews should also be permitted to keep and run their inns, although he recommends that they serve beer rather than vodka. ${ }^{16}$ Other Jewish publicists then in Warsaw, such as Menahem Mendel Lefin of Satanow, formulated proposals and participated in discussions, but were seemingly silent on the issue of the Propinacja. ${ }^{17}$

As pressing as the issues of Jewish reform were to the revitalization of Poland - the shared and stated goal of the participants in the Sejm -, by the spring of 1792 it seemed clear that the Sejm was not going to pass significant reform measures. The Jewish reform question had been turned over to a committee which could not arrive at a consensus and delayed its response. To bring the issue forward again, Hugo Kollątaj submitted a reform proposal to the Sejm on 29 May 1792 with a handwritten note. ${ }^{18}$ Among its recommendations was one that local authorities give permits or conclude agreements entitling Jews to unrestricted trade, craft and industrial activity - a measure which would at once give Jews greater freedom and subject them to a variety of local political and economic controls. In an effort to compromise with opponents of Jewish involvement in the Propinacja, it was suggested that Jews be allowed to brew and distill alcohol in both free and hereditary towns for a trial period of seven years. (This particular point was amended by several deputies to allow innkeeping only at the discretion of local authorities.) Nevertheless, this proposal to implement wide-ranging national reforms failed. Because of this failure, which signalled the Sejm's apparent inability to deal collectively and con-

15 N. Gelber, "Źydzi i zagadnienie reformy Żydów na Sejmie Czteroletnim", in: Miesięcznik Żydowski, X (1931), p. 332; Kh. Shmeruk, "Moshe Markuze fun Slonim un der Mokor fun zayn Bukh Ezer Yisrael”, in: Sefer Dov Sadan, ed. by Sh. Verses, N. Rotenstreich and Kh. Shmeruk (Jerusalem, 1977), pp. 361-82.

16 Materialy z Historii Sejmu Czteroletniego, op. cit., VI, pp. 421-33; Gelber, "Zydzi i zagadnienie reformy Żydów", p. 340.

17 N. Gelber, "Mendel Lefin Satanow" (in Hebrew), in: Abraham Weiss Jubilee (New York, 1964), pp. 271-301.

18 Materialy z Historii Sejmu Czteroletniego, VI, pp. 49 1-97. 
structively with Polish problems, a group of Jewish representatives wrote to the Police Committee with a list of demands, including one that Jews be allowed to run breweries. ${ }^{19}$

After the Third Partition (1795), the issue of the Propinacja continued to be raised by Polish pamphleteers. The Jews' involvement in that monopoly was presented as evidence of their significant contribution to Poland's national tragedy. On the other hand, in the publicistic litterature influenced by Russian autocratic policies, Jewish involvement in the Propinacja was seen as deleterious to the very institution of serfdom, the foundation of the Russian state system. These criticisms, whether Russian or Polish in outlook, were followed either by a variety of reform proposals or by vicious denunciations calling for the expulsion - and worse - of Jews. ${ }^{20}$

The Russian position, which had been developing since that nation first began to administer Polish territories, was reinforced during the last years of the eighteenth century. Certain regional Governors, among them Zakhar Karneev of Belorussia and Ivan Frizel of Lithuania (who was enthusiastically supported by the Lithuanian gentry), indicated in their official reports that the Jews were responsible for "the ruination of the peasants". This could be stopped by eliminating Jews from the Propinacja and by instituting other reforms, such as removing them from the countryside and resettling them in special centers, new and distant areas, or underdeveloped regions; limiting their occupations to agriculture and handicrafts; restricting their communal autonomy; and imposing a dress code. That any of these reforms, even if implemented under ideal circumstances, would involve severe hardships for the Jews was not considered; human anguish was not an important concern in the Polizeiordnungskultur or to the Tsarist civil servant. ${ }^{21}$

In the spring of 1799 and again about a year later, Emperor Paul of Russia ordered an investigation of the peasant rebellions and starvation in the areas of Eastern Poland that had been annexed to Russia. Gavriil Derzhavin, a Russian poet of some standing and a high official in the Emperor's service gentry, was ordered to undertake this investigation.

19 Ibid., p. 499.

20 T. Czacki, Rosprawa o Żydach (Vilna, 1807), p. 220. See also Gelber, "The Program for a Jewish State" (in Hebrew) in: Keneset, III (1939), pp. 291-320; id., "The Jewish Question in Poland in the Years 1815-1830" (in Hebrew), in: Sion, XIII (1948), pp. 106-43, and M. Verte, "Polish Plans for a Territorial Settlement of the Jewish Question" (in Hebrew), ibid., V (1941), pp. 148-55, 203-13.

21 A. Springer, "Gavriil Derzhavin's Jewish Reform Project of 1800", in: CanadianAmerican Slavic Studies, X(1976), p. 21. 
Rather than focusing on the peasant problem, Derzhavin's report made detailed proposals for the reorganization of the Jewish population of the area. ${ }^{22}$ Derzhavin initially cites evidence of the retarded development of peasant agriculture - the insufficient use of fertilizer, antiquated grazing techniques, and the inefficiency of the peasants' small plots for grain growing. But he quickly shifts to a critique of two aspects of grain production: the pernicious effects of the Arenda and the gentry's monopoly on the distribution of alcohol, which was even more often managed by Jews. While reluctant to curtail the traditional rights of the gentry, he argues that some control is needed for the serf's sake.

It is from this position that Derzhavin launches his infamous attacks on Jews and Jewish culture. He makes scathing remarks about the Kahal, the autonomous Jewish communal governing body, claiming that it organizes the Jews into "a state within a state" and thus enables them to harm the peasants, the gentry, and Russia itself. ${ }^{23} \mathrm{He}$ also denounces traditional Jewish education for fostering Jewish intolerance and isolation, and consequently for preventing Jews from becoming "useful citizens". The transformation of noxious Jews into productive citizens is Derzhavin's acknowledged goal, but it is also part of the divine plan: "The Lord God, whose intent has not been revealed to us, has put these dangerous people onto the face of the earth [...], so governments which rule by His mercy must also endure them and must make every effort to insure that they become useful to themselves and to the societies in which they have been established."24 Returning from God's purported plan to the Tsar's specific assignment, Derzhavin shows how Jewish control of alcohol production and distribution impoverishes and demoralizes the serfs, contributes to poor harvests and food shortages, and finally precipitates peasant rebellions. Jews are solely responsible for "ruining the peasantry", and are in dire need of reform, both for their own good and for Russia's. Whether Derzhavin's conclusions arise from ignorance or malice - or both -, it is

22 Ibid., pp. 1-3. For a survey of other proposals formulated by Russian officials at this time, see Ettinger, "Foundations and Purposes", loc. cit., pp. 20-34; also id., "The Reform Proposal of 1804" (in Hebrew), in: He-Avar, XII (1956), pp. 87-110. Other historians emphasize the differences in tone and substance between Derzhavin's and Frizel's proposals. Frizel, the Governor of Lithuania, is supposed to have conveyed more of the spirit of "Enlightened Absolutism" and to have argued for the integration of Jews into Russian society. Ettinger, however, in "The Reform Proposal", pp. 90-110, stresses the similarity of their ideas and plans.

${ }^{23}$ For an analysis of the history of this phrase, see J. Katz, "A State Within a State: The History of an Anti-Semitic Slogan", in: Proceedings of the Israeli Academy of Sciences and Humanities, IV (1971), pp. 29-58.

24 Springer, "Derzhavin's Jewish Reform Project", loc. cit., p. 3; Ettinger, "Foundations and Purposes", pp. 29-33. 
clear that he failed to consider the complex set of economic interests that underlay the liquor monopoly and the peasants' situation in general. ${ }^{25}$

Derzhavin's report was significant not only in the decisiveness of its linkage of the Jewish problem and the peasant problem, and in the comprehensiveness and cruelty of its proposed solutions, but in the influence of its assessments on what came to be public policy. The tone of the Statutes of 1804 was different from that of Derzhavin's report, yet of all its proposals to reform the Jews, one most ruthless in its implications was the proposal closest in spirit to Derzhavin. This was Article 34, which forbade Jews to run inns or taverns and even to reside in villages or thoroughfares after an interval of a few years; by 1807 , when its provisions were to have been effected, sixty thousand families of Jewish innkeepers, according to a contemporary estimate, would have been driven from their communities and would have been economically ruined. A report on the Jewish situation begun in 1809 under the chairmanship of the Privy Councillor V. S. Popov and presented to Alexander I in 1812 attempts to explain why the Jews had not been resettled from the villages to the towns and cities. The postponement of the full implementation of this policy is linked to Napoleon's eastward incursions and his ambiguous overtures to Jews. Decisions of 1807 to moderate this policy are cited in relation to the threat posed by France; it is hinted that displaced and angry Jews might then organize as a "Fifth Column". The intrinsic difficulties in moving so many people in so short a time, the dangers posed by those uprooted for the indigenous population, the current preoccupation with the defense of Russia, all were cited as justifications for the failure of this policy. ${ }^{26}$ In fact, none of the proposals for Jewish reform, including the elimination of Jews from the Propinacja, was pursued thoroughly and consistently. Instead, those proposals became part of a bureaucratic parlance which had a life of its own; they were invoked nationally when needed to explain or justify failure, and locally to extort money from desperate Jews. But even more insidious was their role in propagating the unchallenged notion that Jews in and of themselves were a particularly harmful and unproductive group.

${ }^{25}$ Springer, “Derzhavin's Jewish Reform Project”, p. 23.

26 "Doklad o Evreiakh Imperatoru Aleksandru Pavlovichu, 1812", in : Russkii Arkhiv, XLI (1903), Pt 1, pp. 253-74. I thank Mr L. J. van Rossum for underscoring the importance of this source and sharing a copy of it with me. L. Greenberg, The Jews in Russia (2 vols; New York, 1976), I, pp. 29-30, following Dubnov, refers to the Popov Report, but concludes that after the War of 1812 the policy to evict one half a million Jews was renewed and the task completed. Ettinger, "The Reform Proposal", p. 102 states that "the only actual result of the Edict of 1804 was the beginning of the expulsion of the Jews from the villages." 
III

We can summarize the Polish and Russian attitudes toward the Propinacja and toward Jewish involvement in that organization as follows. First, some members of the Polish gentry recognized the Propinacja's economic utility; Czartoryski, for example, compared it to a mint - another concession often managed by Jews. Second, the earliest debates, which took place in Poland, centered on controlling its profits; the Jews involved in it were condemned not for exploiting the serfs, but for usurping the prerogatives of other sectors of Polish society. And third, it was the Russian service gentry and the bureaucrats supervising the annexed territories who, while recognizing the Polish gentry's role in fostering the Propinacja, singled out the Jews as particularly harmful to the serfs and therefore in need of fundamental reforms.

What is behind the increasingly unfavorable view of the Propinacja and its Jewish managers? How is this change connected with the political and economic transformations then taking place, as the autarky of Polish feudalism weakened and the scope of Russian autocracy expanded? To what extent were economic evaluations of productivity influenced by Western ideologies on the one hand and social structural realities on the other?

The Western Enlightenment began to affect limited but powerful circles in Poland and Russia, creating expectations for reform. But the men and women of the Enlightenment were highly selective in their appropriation of that new "spirit of the West"; in both Poland and Russia, for example, abstract conceptions of human freedom and progress were wholly reconcilable with tolerance of and even support of feudalism. ${ }^{27}$ No less selective were Eastern European readings of Western Enlightenment proposals for the reform of French and German Jews. Similarly, attempts to explain the economic successes of British and Dutch Jews tended to slight the fact that wider opportunities and greater security were available to Jews there. Eastern Jews inevitably suffered by comparison with their co-religionists in the West, and their alleged backwardness was attributed to personal failings or to some kind of innate inferiority. Furthermore, Western conceptions of productivity, which had been generated by the Enlightenment in the last decades of the eighteenth century and which mainly promoted industrial enterprise and agricultural modernization, became the standard by which the function and social location of Eastern

${ }^{27}$ P. Gay, The Enlightenment: An Interpretation (2 vols; New York, 1966-69), II, p. 31. Gay points to common contradictions in Enlightenment humanitarianism. For example, zealous opponents of slavery often tolerated child labor in the mines. 
Jews were assessed. Insufficient attention was paid to the great political and social differences between the two regions, and to how these differences might limit Jewish economic potential. The difficulties in effecting changes on the Western pattern were largely ignored; reforms were to be realized by fiat. The mounting indignation against Jewish involvement in the Propinacja must be seen in this context.

Another factor which contributed to the changing assessment of the Propinacja in the late eighteenth century may have had to do with Russian antisemitism in general and with an antisemitism of Russian officials in particular. Polish antisemitism was not lacking in virulence and was always seeking new forms of expression and areas of application. It undoubtedly influenced the Russian officials' evaluation of the problems in their new territories. But the Poles had centuries of actual experiences with Jews that involved co-operation as well as conflict. ${ }^{28}$ The exclusion of Jews from the Russian Empire until the Partitions preserved the more mythic strains of Russian antisemitism, and may have sharpened the focus of the accusation that the Jews were responsible for the peasants' woes.

Changes in the social structure, however, may also have altered the perception of Jewish productivity. Having examined the political and economic forces which promoted the development of the Propinacja and Jewish participation in it as an integral part of the consolidation of Polish feudal autarky, it remains for us to consider how the new socio-economic context brought about by the decline of Polish feudal autarky and its absorption into the Russian au tocratic state system affected the Propinacja. The annexation of Polish lands to Russia had an important impact on the economies of the feudal estates established in those territories.

Although the alleged harmfulness of the Propinacja was increasingly emphasized, what had in fact happened was that its economic importance had decreased. The Polish gentry, who controlled the rich grain lands of Eastern Poland, had been struggling for over a century to maintain the profitability of their grain crop despite unfavorable market conditions in the West. When these lands were annexed to Russia, which needed Polish grain to feed its urban and interior population and whose grain prices were less influenced by fluctuations in the West, the Polish gentry again had distant and lucrative markets for their grain. ${ }^{29}$ The network of institutions

28 Ettinger, "Foundations and Purposes", p. 22.

29 In his recent study, Immanuel Wallerstein places Russia outside of the European world economy, presenting evidence that Russia did not export grain to the industrializing West, but rather sold wheat on its expanded domestic markets. The Modern World System (New York, 1974), pp. 305-07. For the significance of this domestic wheat trade in the eighteenth century, see R. Crummey, The Old Believers and the World of Antichrist (Madison, 1970), pp. 135-38. 
and the practices connected with the Propinacja continued, though for some members of the gentry - particularly the larger landowners - they were not as useful as they had been. Because of the Propinacja's declining utility and the existence of economic alternatives, the gentry could better afford to join in attacking the Propinacja and its Jewish entrepreneurs. But even after the grain trade was reorganized to suit the post-Partition shift in trade routes, the Propinacja was still useful to the lower gentry. Since they could not profitably participate in more distant markets, the Propinacja served them as a local, occasional "spot market", ensuring the profitable disposal of their grain surpluses. ${ }^{30}$

The array of diverse interests underlying Polish attitudes to the Propinacja and to the Jews involved in it was matched by a new set of considerations - those of the annexationist state. For example, the Russian bureaucracy was restrained from implementing any of its plans for Jewish reform by its concern to preserve, at least in theory, the rights of the Polish gentry. Any altering of the situation of Jews had to be considered in relation to gentry rights. Even though the Polish gentry had to be subordinated to the Russian autocracy and though Polish economic involvements had to be consonant with those of the Russian state, the Tsars at the turn of the nineteenth century - unlike some of their predecessors - tried to avoid direct confrontations with the gentry, especially where the latter's formal rights were concerned. As early as 1786, the Russian government had ruled that the gentry could grant Propinacja concessions so long as it was not detrimental to the public welfare or to the maintenance of order. Although it superficially concerned itself only with the Propinacja and seemed to avoid the principled issue of gentry rights, this law increased the Russians' economic power over the Polish gentry. The repetition of this ruling in 1795 and 1797 is the best evidence that this was not a circumstantial decision, but a consistent Russian administrative tactic to curtail the autonomy of the gentry while preserving its symbolic powers and status.

These policies reflect the altered socio-economic context of the Propinacja and the involvement of Jews within it. The Propinacja's role in the economics of Polish feudalism and its function of maintaining autarky

30 Technical innovations in stills that had been made at this time in the West might have reduced the capital outlay necessary to manufacture grain alcohol. (For a description of the new still technologies and of their social and economic effects, see Rorabaugh, The Alcoholic Republic, op. cit., pp. 69-76.) This might have made it possible for more of the lower gentry and the burghers to contemplate entering this field, and would have encouraged them to try to reduce competition by eliminating the Jews. This seems to have been the case in Lithuania and Belorussia, where the attacks against Jewish involvement in the Propinacja were most vociferous. 
were superseded by its role and function within Russian autocracy. In Russia, serfdom was not merely a mode of labor organization on feudal estates or even an enactment of patriarchal relations, but an integral part of the state system. On the other hand, it was also essential for the Russian autocrats and administrators to uphold the theory of the power of the aristocracy and simultaneously to break its autonomy in both Poland and Russia. Since the time of Ivan IV, the Russian gentry had received its privileges from the political center. Consequently, any economic device which contributed to the gentry's autonomy conflicted with centralizing political forces. If the Jews were harming and exploiting the peasant labor-force, they were also impeding the subordination of the gentry. In the Arenda system in general and in the Propinacja in particular, the Jews had functioned as a service gentry to the Polish gentry; now they had to be absorbed into the Russian autocratic state. Thus proposals to remove them from villages had a dual purpose: to curtail their allegedly harmful effect upon the serfs, and to remove them from the domain of, and therefore to weaken, the gentry. The elimination of Jews from the Propinacja and their resettlement away form the gentry and the serfs, the dissolution of their communal structures, and the enforcement of dress codes and other restrictions were part of the effort to organize and to enlist them within the Russian autocratic state system.

This points to a motive and an outer limit for Jewish reform in the areas of Poland annexed to Russia. The effort to make Jews fit better into the state structure of autocratic Russia had to be conducted so as to preserve the institutions of serfdom and the aristocracy. It also had to promote the incorporation of Poland's rich farmlands, its quarrelsome gentry and its rebellious peasantry into the Russian state system and its economy. This complex network of factors and groups presented problems as well as opportunities for Russian policymakers. One way they tried to solve those problems was to blame the Jews for them - a tactic that masked the forces of change which were becoming ever more difficult to control.

The desire to preserve Russia's rigid social system defined the limits of all reform and inhibited Russian and Jewish economic development. Within that system, the Jews occupied a precarious position between the gentry and the serfs. On the one side, Jews were denied certain rights enjoyed by the gentry that motivated capital accumulation and investment; on the other, they rejected the hardships and bondage endured by the serfs that were the foundation of the feudal agricultural system. These established conditions effectively sabotaged any reform proposals to promote industry and agriculture - the new terms of productivity - among the Jews on a large scale. Consequently, it may not only be a function of 
"conservatism" or "traditionalism", as was often claimed by the impatient and disgruntled modernizers, that a large segment of the Jewish community responded to the rhetoric of reform with growing suspicion. In addition, the contradictory terms of the reform proposals and the equivocal intentions of the reformers were rooted in a socio-economic context influenced by Polish antisemitism and by a group of Russian factors: residues of medieval antagonism toward Jews; provincial, xenophobic and incompetent administrators; and variations in the Tsars' attitudes toward Jews, which ranged from Catherine Il's Enlightenment pretensions to Alexander I's vacillations to Nicholas I's undisguised tyranny. The imposition of Western ideas on Eastern settings had an ironic fate: the same Enlightenment ideologies which in their selective application had generated the rhetoric of reform also limited its realization and contributed to its failure. 